\title{
Odporność kawitacyjna powłok na osnowie niklu napawanych metodą płomieniowo-proszkową
}

\author{
Cavitation erosion resistance of coating flame deposited \\ with nickel base powder
}

\section{Streszczenie}

W pracy przedstawiono wyniki pomiarów odporności na zużycie kawitacyjne powłok na osnowie Ni. Powłoki wykonano metodą napawania płomieniowo-proszkowego. Badania kawitacyjne wykonano na stanowisku wibracyjnym zgodnie z normą ASTM G-32.

Określono wpływ mikrostruktury, twardości i mikrotwardości wytworzonych warstw na ich odporność kawitacyjną. Przy użyciu mikroskopii elektronowej dokonano identyfikacji mechanizmu zużywania powłok. Obserwacji dokonano w oznaczonych obszarach na powierzchni powłok w wybranych czasach ekspozycji. Powłoki objęte badaniami mogą być rozważane do regeneracji elementów maszyn i urządzeń podlegających zużyciu kawitacyjnemu.

Słowa kluczowe: powłoka na osnowie niklu, erozja kawitacyjna, metoda płomieniowo-proszkowa

\section{Abstract}

In the work results of cavitation erosion test of nickel based coatings were presented. Coatings were pad welded with the oxy-acetylene powder torch. Cavitation tests were conducted on vibratory test rig according do ASTM G-32 standard. The influence of microstructure, hardness and microhardness on cavitation erosion resistance was investigated. The cavitation erosion mechanism was examined by using SEM microscopy. Observations were conducted in specified areas of coatings in defined times of exposition. Presented coatings could be considered to repair cavitation worn machines elements and appliance.

Keywords: nickel based coating, cavitation erosion, flame-powder pad welding

\section{Wstęp}

Kawitacja jest to zjawisko polegające na powstawaniu w obszarach obniżonego ciśnienia cieczy i gwałtownemu znikaniu w obszarach o wyższym ciśnieniu bąbli gazowych. Zjawisko to może występować m.in. w instalacjach przepływowych, silnikach wysokoprężnych, urządzeniach i instalacjach inżynierii procesowej. Nie zawsze istnieje możliwość wyeliminowania zjawiska kawitacji a powierzchnie elementów maszyn i urządzeń podlegające jej oddziaływaniu mogą ulegać niszczeniu - erozji kawitacyjnej.

W celu ochrony przed zużywaniem kawitacyjnym, regeneracji elementów lub wydłużenia okresu eksploatacji elementów maszyn i urządzeń stosowane mogą być różne spawalnicze metody konstytuowania powłok. Napawanie płomieniowo-proszkowe warstw na osnowie niklu jest w warunkach przemysłowych metodą wygodną [1 $\div 4]$.

Źródła literaturowe podają głównie wyniki badań odporności powłok niklowych na zużycie ścierne, erozyjne i korozyjne np. $[4 \div 8]$. W przeciwieństwie do stopów na osnowie

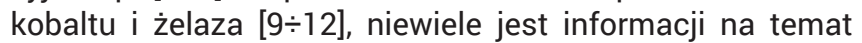
odporności kawitacyjnej powłok na osnowie niklu lub zawie-

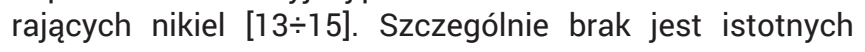

informacji dotyczących mechanizmu zużywania kawitacyjnego powłok niklowych nałożonych metodą płomieniowoproszkową.

Celem pracy jest określenie odporności kawitacyjnej stopów na osnowie niklu napawanych metodą płomieniowoproszkową.

\section{Metodyka badań, materiał do badań}

Powłoki na osnowie niklu wytworzono z komercyjnych proszków (Tabela I) metodą napawania płomieniowo-proszkową na płytach ze stali gat. S235JR. Powierzchnię płyt próbnych czyszczono mechanicznie i odtłuczono. Parametry procesu wykonania powłok zawarto w tablicy II.

Wymiary płyt próbnych, napawanych powłok oraz miejsce wycięcia próbek do badań przedstawiono na rysunku 1. Obrobione mechanicznie próbki mały wymiary $25 \times 10 \mathrm{~mm}$, w tym grubość powłok wynosiła ok. $3 \mathrm{~mm}$. Powierzchnię powłok przed badaniami kawitacyjnymi szlifowano i polerowano uzyskując wartość Ra nie większą niż 0,06 $\mu \mathrm{m}$. Pomiaru chropowatości dokonano za pomocą profilometru SURTRONIC 3+ (prod. Taylor Hobson). Przygotowano

Mgr inż. Mirosław Szala, prof. dr hab. Tadeusz Hejwowski - Politechnika Lubelska. 
Tablica I. Nominalne składy chemiczne proszków wg danych producentów

Table I. Normalized chemical composition of powders according to manufacturer's data

\begin{tabular}{|c|c|c|c|c|c|c|c|}
\hline \multirow{2}{*}{$\begin{array}{c}\text { Oznaczenie } \\
\text { próbki }\end{array}$} & \multirow{2}{*}{ Nazwa handlowa } & \multicolumn{6}{|c|}{ Nominalny skład chemiczny [\% wag.] } \\
\cline { 3 - 8 } & & $\mathrm{B}$ & $\mathrm{C}$ & $\mathrm{Cr}$ & $\mathrm{Fe}$ & $\mathrm{Ni}$ & $\mathrm{Si}$ \\
\hline 1 & PMNi-35G & 1,6 & 0,1 & - & 1,5 & reszta & 3,4 \\
\hline 2 & Amil AMI 1045 & 2,8 & 0,2 & 11,9 & 3,7 & reszta & 3,1 \\
\hline 3 & Deloro Alloy Stellite 60 & 3,5 & 0,7 & 15 & 4 & reszta & 4,5 \\
\hline
\end{tabular}

po trzy próbki z każdego z materiałów. Przy użyciu mikrotwardościomierza FM800 (prod. Future-Tech) zmierzono mikrotwardość HV0,01 w 15 losowo wybranych punktach na powierzchni powłok. Zmierzono twardość HV30 dla każdej powłoki. Wykonano odciski referencyjne. Posłużyły one do oznaczenia miejsc obserwacji zmian topografii powierzchni powłok dokonywanych po różnych czasach ekspozycji na działanie kawitacji, w przedziale od 0 do 300 minut.

Tablica II. Parametry wykonania powłok Table II. Parameters of coatings deposition

\begin{tabular}{|c|c|c|c|}
\hline \multirow{2}{*}{$\begin{array}{c}\text { Typ } \\
\text { palnika }\end{array}$} & \multicolumn{2}{|c|}{ Ciśnienie gazu (MPa) } & \multirow{2}{*}{$\begin{array}{c}\text { Rodzaj } \\
\text { płomienia }\end{array}$} \\
\cline { 2 - 3 } & $\mathrm{O}_{2}$ & $\mathrm{C}_{2} \mathrm{H}_{2}$ & Neutralny \\
\hline SPT-100 & $0,4 \pm 0,6$ & $0,04 \pm 0,06$ & Nen \\
\hline
\end{tabular}

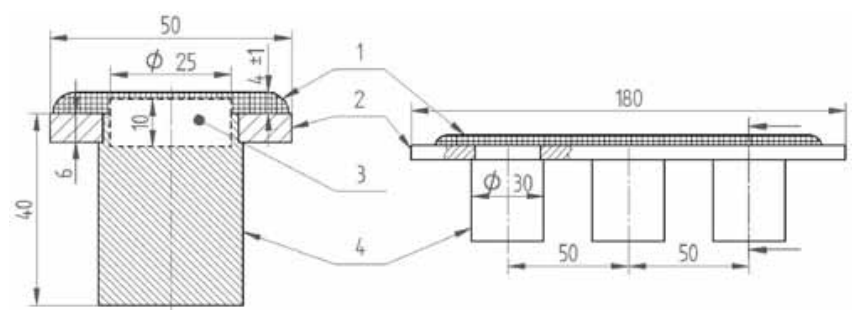

Rys. 1. Lokalizacja miejsca pobrania próbki z płyty próbnej: 1 - powłoka, 2 - płyta, 3 - miejsce wycięcia próbki, 4 - trzpień Fig. 1. Location of sample cut out from the testing plate: 1 - coating, 2 - plate, 3 - location of sample cut out, 4 - mandrel

Do przeprowadzenia badań kawitacyjnych użyto stanowiska wibracyjnego którego schemat przedstawiono na rysunku 2. Badania prowadzono w oparciu o normę ASTM G32-03 [16] dla próbki stacjonarnej. Badania wykonano w wodzie destylowanej, której temperaturę utrzymywano w zakresie $25 \pm 2^{\circ} \mathrm{C}$. Nad stacjonarną próbką w odległości $1 \mathrm{~mm}$ znajdowała się drgająca końcówka sonotrody. Drgania zanurzonej w wodzie sonotrody wywoływały powstawanie kawitacji. Częstotliwość drgań sonotrody wynosiła $20 \mathrm{kHz}$, amplituda $50 \mu \mathrm{m}$, moc generatora ultradźwięków 500W, pole powierzchni czynnej próbki 379,9 mm². Określono ubytek masy próbek z dokładnością do 0,1 mg. Obliczono względne zużycie kawitacyjne jako stosunek ubytku masy materiału badanego do referencyjnego testowanego w tych samych warunkach. Materiał referencyjny (oznaczono nr 4) stanowiła stal gat. X5CrNi18-10 (C $\leq 0,07 \% ; \mathrm{Si} \leq 1 \% ; \mathrm{Mn} \leq 2 \% ; \mathrm{P} \leq 0,045 \%$; $\mathrm{S} \leq 0,015 \% ; \mathrm{N} \leq 0,11 \% ; \mathrm{Cr}=17,5-19,5 \% ; \mathrm{Ni}=8-10,5 \% ; \mathrm{Fe}-$ reszta). Przy użyciu mikroskopów stereoskopowego SMZ 1500 (prod. Nikon) i skaningowego elektronowego Phenom Pro $\mathrm{X}$ (prod. Phenom-World BV) obserwowano zmiany powierzchni powstałe wskutek zużycia kawitacyjnego powierzchni próbek oraz wykonano punktową mikroanalizę składu chemicznego metodą EDS. W celu identyfikacji przebiegu procesu zużywania powłok, w określonych odstępach czasu wykonano fotografie powierzchni powłok w uprzednio oznaczonych obszarach. Wygląd określonych obszarów przemienionych po różnych czasach ekspozycji porównano z odpowiadającymi im obszarami przed badaniami. Zmierzono wartości parametru profilu chropowatości $\mathrm{Ra}$ w minimum 5 losowo wybranych obszarach na powierzchni zużycia kawitacyjnego każdej z próbek.

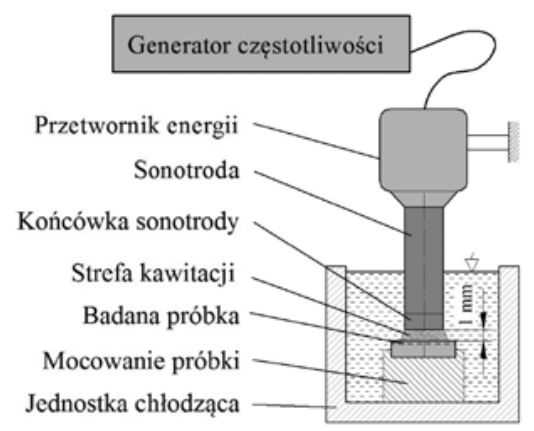

Rys. 2. Schemat urządzenia wibracyjnego

Fig. 2. Schematic diagram of ultrasonic equipment

\section{Wyniki badań i ich dyskusja}

\section{Wpływ mikrostruktury i twardości na odporność kawitacyjną}

Budowa strukturalna i właściwości materiałów wpływają na odporność kawitacyjną i na przebieg procesu zużywania kawitacyjnego materiałów. Jak podają autorzy prac $[17,18]$ na odporność kawitacyjną wpływa wiele parametrów określających właściwości mikrostruktury materiałów takie jak jednorodność budowy, plastyczność, właściwości stereometryczne warstwy wierzchniej oraz wielkość i rodzaj wydzieleń składników mikrostruktury. Twardość materiałów postrzegana jest jako główny czynnik determinujący odporność kawitacyjną, rysunek 3 [17].

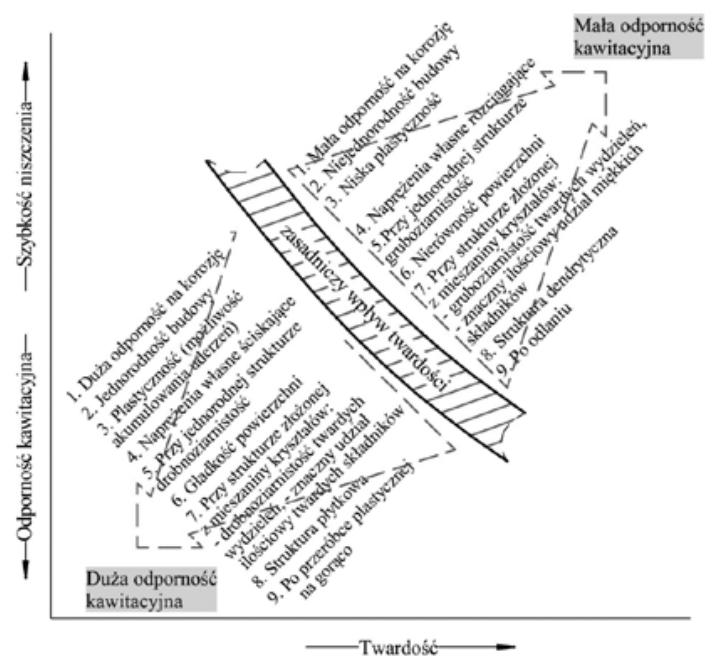

Rys. 3. Zależność odporności stopów metali na działanie kawitacji od ich właściwości fizyko-chemicznych i strukturalnych, na podstawie [17]

Fig. 3. Relationship between cavitation erosion of metal alloys and their physicochemical and structural prosperities, according to [17] 
Na podstawie analizy mikrostruktury wytworzonych powłok (rys. $4 \div 6$ ) oraz danych literaturowych $[19,20]$ można stwierdzić iż mikrostruktura wytworzonych powłok składa się roztworu stałego niklu y oraz różnych eutektyk, w tym Ni$\mathrm{Ni}_{3} \mathrm{~B}$. W powłokach zawierających chrom 2 (rys. 5) i 3 (rys. 6), występują m.in. węgliki np. $\mathrm{Cr}_{7} \mathrm{C}_{3}$, borki oraz jak opisuje Kim et al. [21] powłoki zwierające powyżej $2 \%$ B mogą zawierać bardzo twarde wydzielenia CrB (punkty: 3C, 4D i 2C w tablicy III oraz rys. 5 i 6). Powłoka 1 (rys. 6) cechowała się grubodendrytyczną strukturą pierwotną i zawierała dendryty roztworu stałego niklu i eutektykę ( $\left.\mathrm{Ni}^{-} \mathrm{Ni}_{3} \mathrm{~B}\right)$ umieszczoną międzydendrytycznie. Stalowa próbka referencyjna 4 cechowała struktura austenityczna.

Odporność na zużycie kawitacyjne badanych próbek rosła w kolejności 1, 4, 2 oraz 3 (rys. 7). Powłoki 2 i 3 zawierające większą ilość B, C oraz $\mathrm{Cr}$ (tablice I i III) odznaczały się niższym zużyciem kawitacyjnym w porównaniu do powłoki 1 nie zawierającej Cr. Mikrostruktura powłok zawierająca borki i węgliki sprzyja wzrostowi odporności kawitacyjnej powłok.

Odnotowano związek pomiędzy twardością próbek i względnym zużyciem kawitacyjnym powłok (rys. 7 i 8). Powłoki twardsze cechuje większa odporność na działanie kawitacji. Powłoki 2 i 3 wykazywały ok. trzykrotnie wyższą wartość twardości oraz ok. ośmiokrotnie dla pow. 3 i ok. trzykrotnie dla powłoki 2 mniejsze względne zużycie kawitacyjne od próbki referencyjnej. Powłoka 1 pomimo wyższej wartości twardości od próbki referencyjnej wykazywała większe zużycie (rys. 7). Podobne zależności otrzymano w wyniku porównania wartości mediany mikrotwardości HV0,01 oraz względnego zużycia kawitacyjnego (rys. 8).

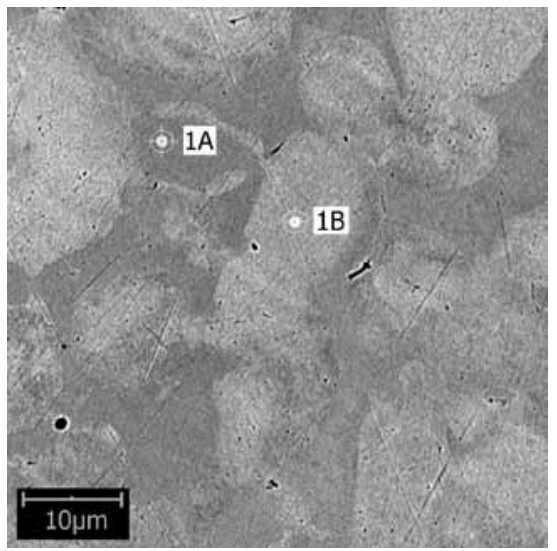

Rys. 4. Wybrany do obserwacji obszar powierzchni powłoki 1 (SEM) Fig. 4. Surface area of coating 1 selected for observation (SEM)

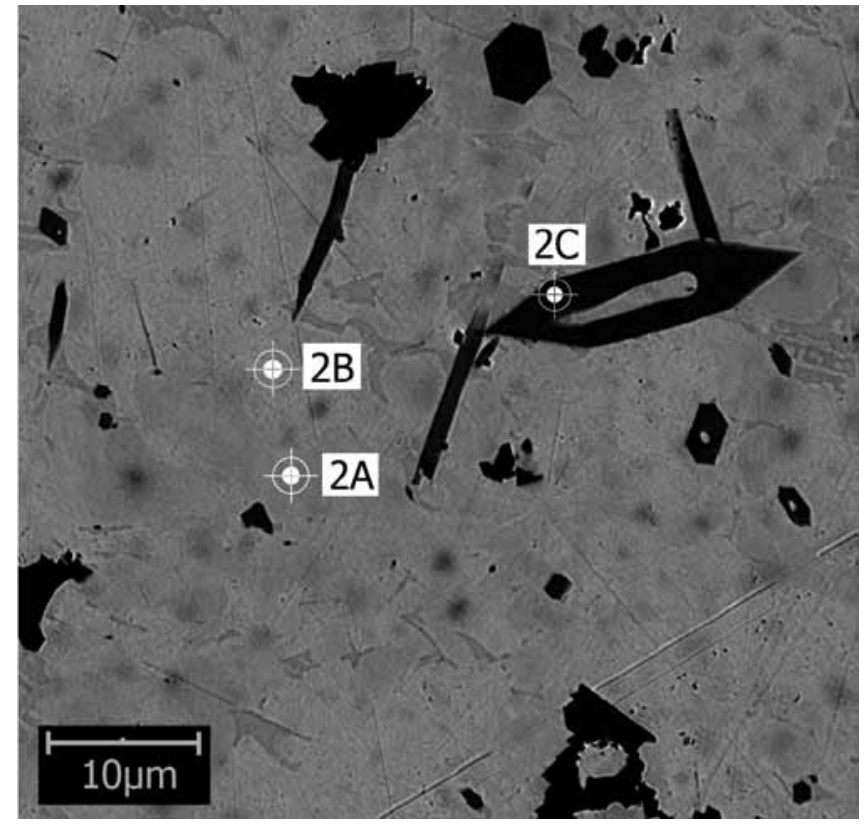

Rys. 5. Wybrany do obserwacji obszar powierzchni powłoki 2 (SEM) Fig. 5. Surface area of coating 2 specified for observation (SEM)

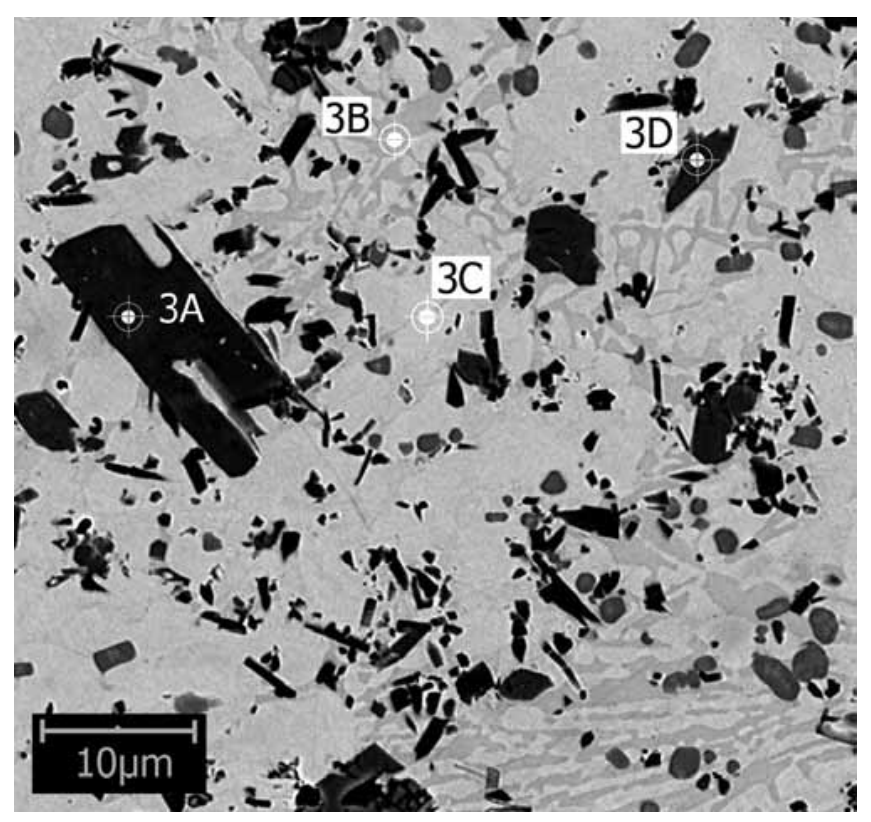

Rys. 6. Wybrany do obserwacji obszar powierzchni powłoki 3 (SEM) Fig. 6. Surface area of coating 3 specified for observation (SEM)

Tablica III. Wyniki analizy składu chemicznego w punktach oznaczonych na Rys $4 \div 6$

Table III. Results of chemical composition analysis in points marked in Fig. $4 \div 6$

\begin{tabular}{|c|c|c|c|c|c|c|}
\hline \multirow{3}{*}{ Powłoka } & \multirow{2}{*}{$\begin{array}{c}\text { Punkt } \\
\text { pomiarowy }\end{array}$} & \multicolumn{5}{|c|}{ Pierwiastek [\% wag.] } \\
\cline { 3 - 7 } & 1A & C & Cr & Ni & Si & Fe \\
\hline \multirow{3}{*}{1} & 1B & $0,7 \pm 0,2$ & - & $95,1 \pm 0,3$ & $2,9 \pm 0,1$ & $1,3 \pm 0,1$ \\
\cline { 2 - 7 } & 2A & $1,6 \pm 0,2$ & $2,2 \pm 0,1$ & $84,8 \pm 0,3$ & $9,9 \pm 0,1$ & $1,4 \pm 0,1$ \\
\hline \multirow{3}{*}{2} & 2B & $0,4 \pm 0,1$ & $10,6 \pm 0,1$ & $82,3 \pm 0,3$ & $4,1 \pm 0,1$ & $5,9 \pm 0,1$ \\
\cline { 2 - 7 } & 2C & $2,7 \pm 0,1$ & $74,4 \pm 0,2$ & $18,5 \pm 0,2$ & $1,1 \pm 0,1$ & $3,3 \pm 0,1$ \\
\hline \multirow{3}{*}{3} & 3A & $6,5 \pm 0,3$ & $82,6 \pm 0,4$ & $8,7 \pm 0,3$ & $0,6 \pm 0,1$ & $1,5 \pm 0,2$ \\
\cline { 2 - 7 } & 3B & $2,5 \pm 0,3$ & $8,5 \pm 0,1$ & $80,3 \pm 0,7$ & $11,4 \pm 0,1$ & $2,2 \pm 0,1$ \\
\cline { 2 - 7 } & 3C & $3,5 \pm 0,3$ & $4,8 \pm 0,1$ & $85,4 \pm 0,7$ & $3,0 \pm 0,1$ & $3,2 \pm 0,1$ \\
\hline
\end{tabular}




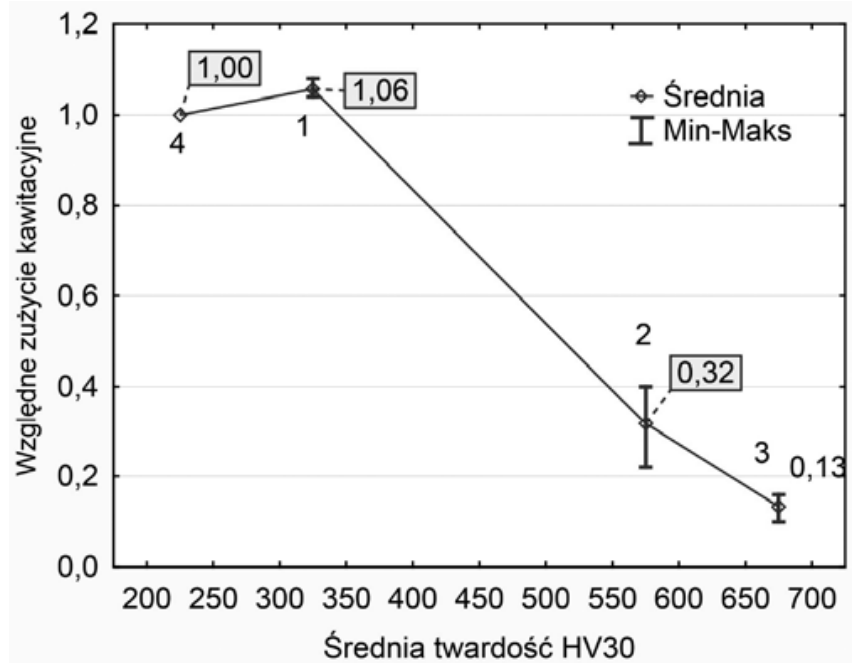

Rys. 7. Względne zużycie kawitacyjne po 300 minutach badań w zależności od twardości

Fig. 7. Relative cavitation wear after 300 minutes of test vs hardness

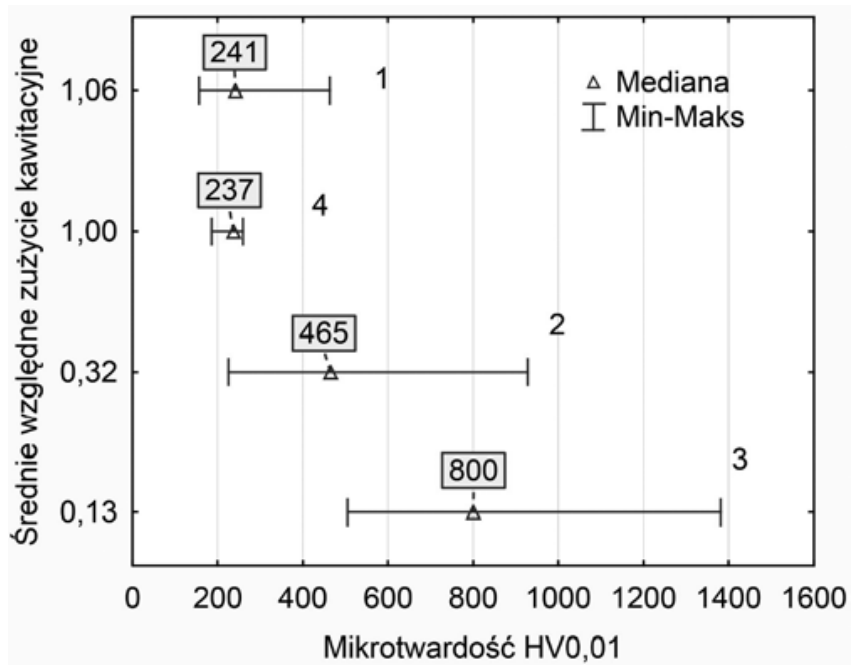

Rys. 8. Zużycie kawitacyjne po 300 minutach badań w zależność mikrotwardości

Fig. 8. Cavitation wear after 300 minutes of test vs microhardness

\section{Charakterystyka zjawiska erozji kawitacyjnej badanych materiałów}

Kawitacja należy do procesów zmęczeniowych a jej oddziaływanie na powierzchnię elementów ma przebieg losowy i zależne jest m.in. od natężenia zjawiska. Należy nadmienić, iż urządzenie wibracyjne cechuje stosunkowo wysokie natężenie zjawiska kawitacji w porównaniu do stanowisk o innej konstrukcji [22] lub do nasilenia erozji kawitacyjnej zachodzącej w warunkach eksploatacyjnych [23].

Niszczenie próbki referencyjnej (4) odpowiada mechanizmowi zużywania przedstawionemu w pracach $[10,12]$. Po stosunkowo krótkim czasie ziarna austenitu podlegają deformacji plastycznej (obserwowano zmatowienie powierzchni na skutek bliźniakowania) a w późniejszych okresach niszczenia kawitacyjnego odnotowywano pojawienie się pęknięć i erozję ziaren obserwowanego obszaru. Po 300 minutach testu (rys. 9) odkształcona i miejscami spękana powierzchnia podlegała selektywnej ekstrakcji. $\mathrm{Na}$ rysunku 9 widoczne są pęknięcia zdeformowanych obszarów oraz miejsca usuwania materiału.

$\mathrm{Na}$ rysunkach $10 \div 12$ przedstawiono miejsca po czasie ekspozycji 300 minut którym odpowiadają kolejno fotografie obszarów powierzchni przygotowane do badań kawitacyjnych odpowiednio, rysunek $4 \div 6$. Na podstawie obserwacji powierzchni powłok prowadzonej po różnych czasach ekspozycji, w oznaczonych obszarach, stwierdzono, iż dla próbki 1 (rys. 10) odkształceniu plastycznemu na skutek oddziaływania kawitacji w pierwszym etapie erozji kawitacyjnej podlegają dendrytyczne obszary oznaczone jako 1A (rys. 4). Następnie usuwane są obszary oznaczone jako 1B. W początkowym okresie zużycia następowato odkształcanie plastyczne obszarów miedzydedrytycznych, następnie obserwowano usuwanie i/lub wykruszanie (widoczne pęknięcia na rys. 10) zdeformowanych składników mikrostruktury rozpoczynające się na granicy faz. Podobnie inicjowanie mechanizmu rozpoczynające się na granicy faz, obserwowano dla powłok Ni-Co w pracy [13]

W pierwszym etapie erozji kawitacyjnej powłoki 2 następuję odkształcenie plastyczne powierzchni, kolejnie

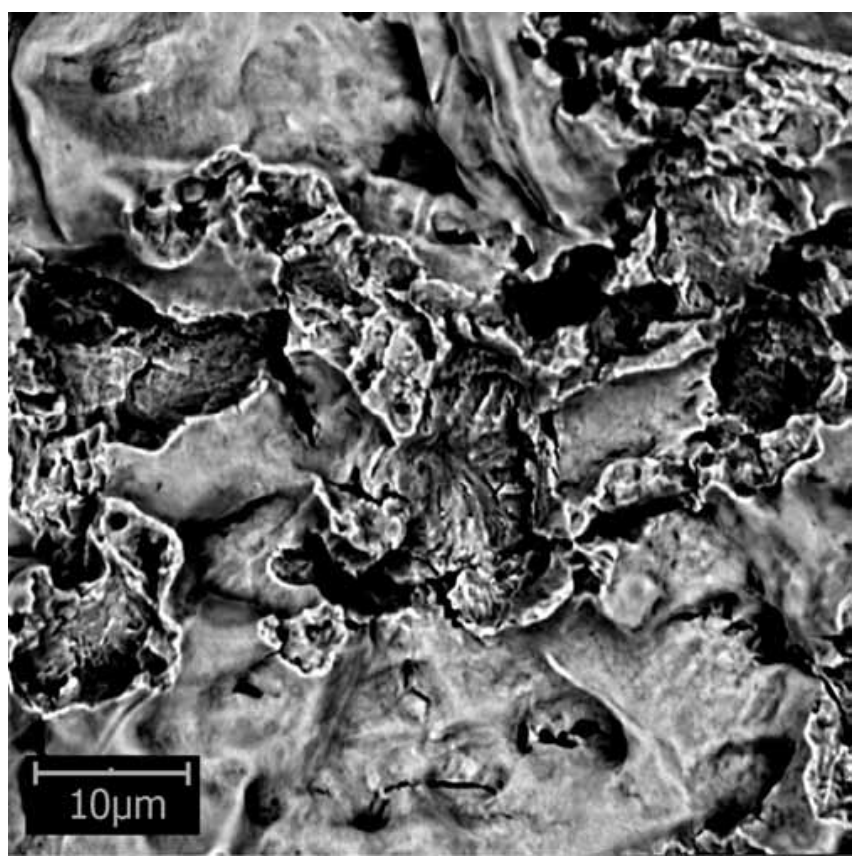

Rys. 9. Obszar powierzchni próbki referencyjnej po 300 min badań kawitacyjnych (SEM)

Fig. 9. Surface area of reference sample after $300 \mathrm{~min}$ of cavitation erosion test (SEM)

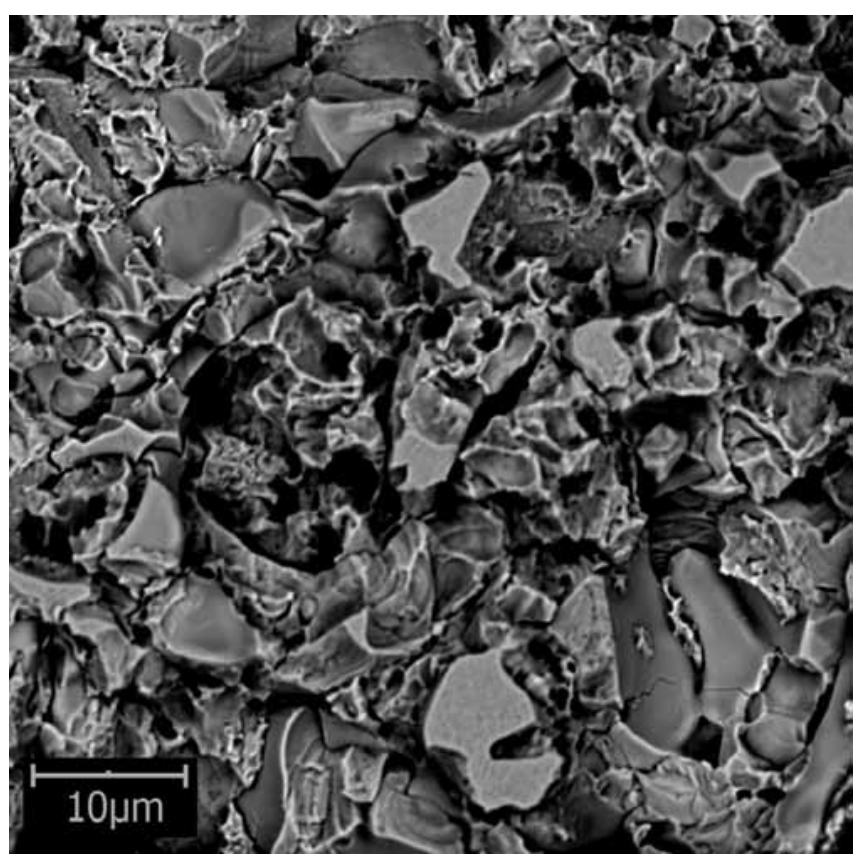

Rys. 10. Obszar powierzchni powłoki 1 przedstawiony na rysunku 4 po 300 min badań kawitacyjnych (SEM)

Fig. 10. Surface area of coating 1 presented in Fig. 4 after 300 min of cavitation test (SEM) 
usuwane są przemienione obszary znajdujące się na granicy faz. Na podstawie obserwacji procesu niszczenia, realizowanych po różnych czasach ekspozycji, stwierdzono iż w pierwszej kolejności usuwanie są obszary dendrytów o niższej zawartości Si (tablica III p. 2B), później obszary zawierające więcej Si (tablica III p. 2A). Odsłonięte zostają brzegi twardych cząstek o rozmiarach zbliżonych do $15 \mu \mathrm{m}$ (rys. 5 p. 2C) oraz wydzielenia eutektyczne. Na rysunku 11 widoczne jest odkształcenie plastycznie zerodowanych obszarów oraz pęknie węglika chromu. Niszczeniu powłoki 3 (rys. 12 ) podlegały obszary osnowy (p. $3 \mathrm{C}$ rys. 6 ) przylegające do skupisk drobnych cząstek o wielkości poniżej $3 \mu \mathrm{m}$ (p. 3D rys. 6) i usuwane były się jako pierwsze. Również wybrane drobne wydzielenia ulegały ekstrakcji z osnowy. Po 300 minutach ekspozycji, obszary eutektyczne oraz wydzielenia węglikowe lub borkowe o rozmiarach ok. $15 \mu \mathrm{m}$ (p. 3A rys. 6) pozostawały w osnowie metalowej powłoki. Powłokę 3 cechowało najwyższa odporność na działanie kawitacji oraz największe rozdrobnienie mikrostruktury, co stanowi potwierdzenie wyników uzyskanych przez A.Sang et al. w pracy [15]. Obecność drobnych wydzieleń, wpływa na wzrost odporności kawitacyjnej powłok na osnowie niklu.

Próbki o znacznym ubytku masy 1, 4 i 2 w porównaniu do próbki 3 odznaczały się również większymi wartościami oraz większym rozrzutem parametru Ra w porównaniu do powłoki 3 (rys. 13). Powłoka 1 i próbki 4 po 300 min badań cechowały się stosunkowo równomiernie zerodowaną powierzchnią oraz zbliżonymi wartościami średnimi parametru Ra i względnej odporności kawitacyjnej. Powłoki 3 i 2 charakteryzowało zużycie selektywne, występowanie obszarów nieprzemienionych i zerodowanych.

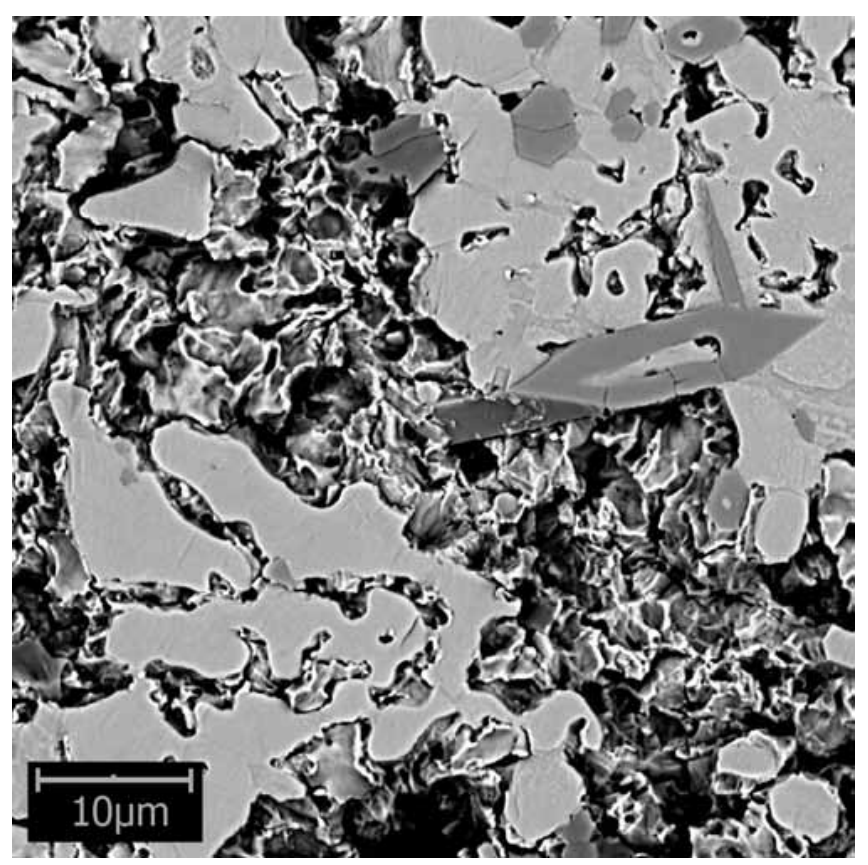

Rys. 11. Obszar powierzchni powłoki 2 przedstawiony na rysunku 5 po 300 min badań kawitacyjnych (SEM)

Fig. 11. Surface area of coating 2 presented in Fig. 5 after 300 min of cavitation test (SEM)
W czasie obserwacji w kolejnych odstępach czasu, zauważono iż obszary podlegające niszczeniu powiększały się kosztem obszarów nieprzeminionych oraz pojawiały się nowe ogniska erozji. Dla powłoki 3 uzyskano najniższe wartości parametru Ra (rys. 13). Wynikało to z przebiegu mechanizmu zużywania, który cechowało znacznie mniejsze odkształcenie plastyczne i stosunkowo mniejsze powierzchnie obszarów zajętych erozją w porównaniu do pozostałych próbek.

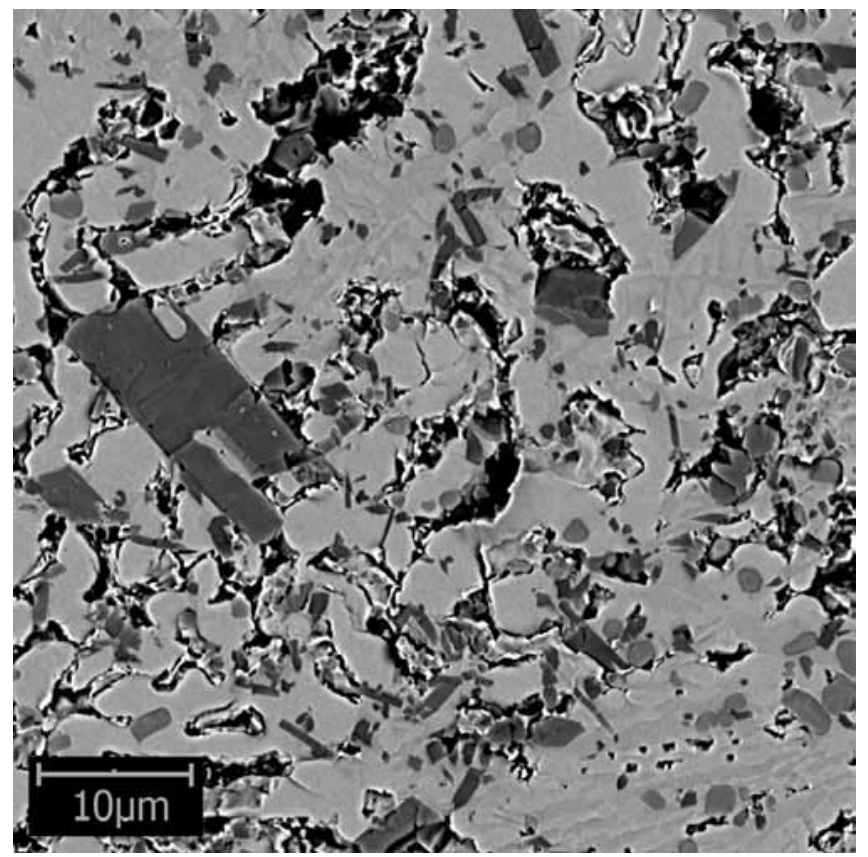

Rys. 12. Obszar powierzchni powłoki 3 przedstawiony na rysunku 6 po 300 min badań kawitacyjnych (SEM)

Fig. 12. Surface area of coating 3 presented in Fig. 6 after 300 min of cavitation test (SEM)

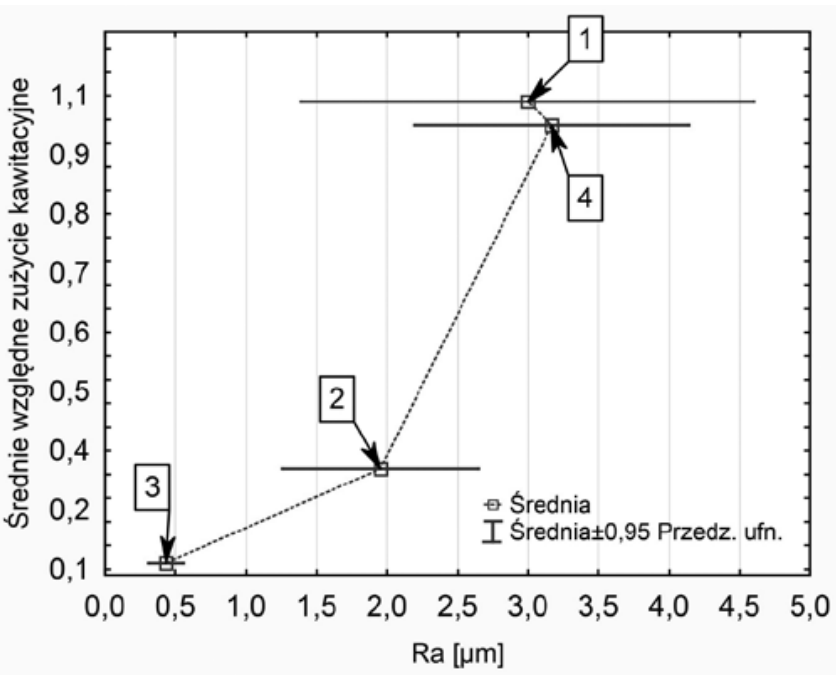

Rys. 13. Zależność zużycia kawitacyjnego od średniej wartości parametru Ra

Fig. 13. Relationship between cavitation wear and average value of Ra parameter

\section{Podsumowanie}

Budowa strukturalna i właściwości powłok wpływają na ich odporność kawitacyjną oraz na przebieg procesu zużywania kawitacyjnego. Powłoki na osnowie niklu o twardości powyżej 500HV charakteryzuje stosunkowo niska wartość względnego zużycia. Mikrostruktura powłok zawierająca eutektyki, wydzielenia twardych cząstek oraz podwyższona zawartość boru, węgla oraz chromu, korzystnie wpływają na odporność kawitacyjną powłok. 
Mechanizm niszczenia kawitacyjnego powłok na osnowie niklu polegał na odkształcaniu obszarów roztworu niklu, usuwaniu obszarów przemienionych inicjowanym na granicy faz oraz częściowym usuwaniu drobnych wydzieleń i obszarów do nich przylegających. Wydzielenia o rozmiarach $15 \mu \mathrm{m}$ nie były usuwane z powłok.

Po 5 godzinach ekspozycji na działanie kawitacji, w porównaniu do stalowej próbki referencyjnej oraz próbki 1, powłoki 2 i 3 wykazały mniejsze względne zużycie kawitacyjne i cechowały się mniejszymi zmianami wartości parametru Ra.

Najlepszą odporność na działanie kawitacji uzyskała próbka 3 dla której uzyskano 8-krotnie niższą wartość względnego zużycia kawitacyjnego w porównaniu do próbki referencyjnej wykonanej ze stali austenitycznej.

\section{Literatura}

[1] A. Kumar, J. Boy, R. Zatorski, L.D. Stephenson, Thermal spray and weld repair alloys for the repair of cavitation damage in turbines and pumps: A technical note, (2005) 177-182.

[2] A. Klimpel, Napawanie i natryskiwanie cieplne: technologie, WNT, 2009.

[3] J. Pilarczyk, Poradnik inżyniera - Spawalnictwo. Tom I, II, Wydawnictwo WNT, Warszawa, 2005

[4] R. González, M.A. García, I. Peñuelas, M. Cadenas, M. del R. Fernández, A.H. Battez, et al., Microstructural study of NiCrBSi coatings obtained by different processes, Wear. 263 (2007) 619-624. doi:10.1016/j.wear.2007.01.094.

[5] T. Hejwowski, Nowoczesne powłoki nakładane cieplnie odporne na zużycie ścierne i erozyjne, Lublin University of Technology, 2013.

[6] P.F. Mendez, N. Barnes, K. Bell, S.D. Borle, S.S. Gajapathi, S.D. Guest, et al., Welding processes for wear resistant overlays, Journal of Manufacturing Processes. 16 (2014) 4-25. doi:10.1016/j.jmapro.2013.06.011.

[7] M. Zwierzchowski, Struktura, właściwości i odporność na zużycie powłok na osnowie kobaltu, Przegląd Spawalnictwa. R. 80, nr 1 (2008) 25-30.

[8] Z. Bergant, U. Trdan, J. Grum, Effect of high-temperature furnace treatment on the microstructure and corrosion behavior of NiCrBSi flame-sprayed coatings, Corrosion Science. 88 (2014) 372-386. doi:10.1016/j.corsci.2014.07.057.

[9] I.J. Karassik, Pump handbook, McGraw-Hill, New York, 2001.

[10] S. Hattori, N. Mikami, Cavitation erosion resistance of stellite alloy weld overlays, Wear. 267 (2009) 1954-1960. doi:10.1016/j. wear.2009.05.007.

[11] M. Szkodo, Cavitation erosion of laser processed Fe-Cr-Mn and Fe-CrCo alloys, Journal of Achievements in Materials and Manufacturing Engineering. Vol. 31 (2008) 378-384.

[12] M. Szkodo, Erozja kawitacyjna materiałów konstrukcyjnych metalowych, Wydawn. Politechniki Gdańskiej, 2008.
[13] M. Szala, T. Hejwowski, I. Lenart, Cavitation erosion resistance of $\mathrm{Ni}$ Co based coatings, Advances in Science and Technology - Research Journal. 8 (2014) 36-42.

[14] H. Hiraga, T. Inoue, H. Shimura, A. Matsunawa, Cavitation erosion mechanism of NiTi coatings made by laser plasma hybrid spraying, Wear. 231 (1999) 272-278. doi:10.1016/S0043-1648(99)00133-7.

[15] K. Sang, Y. Li, Cavitation erosion of flame spray weld coating of nickel-base alloy powder, Wear. 189 (1995) 20-24. doi:10.1016/00431648(95)06608-X.

[16] ASTM G32-03 Standard Test Method for Cavitation Erosion Using Vibratory Apparatus, ASTM International, 2003.

[17] K. Steller, O mechanizmie niszczenia materiałów podczas kawitacji, IMP PAN, 1983.

[18] S. Hattori, R. Ishikura, Revision of cavitation erosion database and analysis of stainless steel data, Wear. 268 (2010) 109-116. doi:10.1016/j.wear.2009.07.005.

[19] Z. Bergant, J. Grum, Quality Improvement of Flame Sprayed, Heat Treated, and Remelted NiCrBSi Coatings, J Therm Spray Tech. 18 (2009) 380-391. doi:10.1007/s1 1666-009-9304-7.

[20] ASM handbook Volume 3: Alloy phase diagrams, ASM International, 1992.

[21] H.-J. Kim, S.-Y. Hwang, C.-H. Lee, P. Juvanon, Assessment of wear performance of flame sprayed and fused Ni-based coatings, Surface and Coatings Technology. 172 (2003) 262-269. doi:10.1016/S02578972(03)00348-7.

[22] T.J. Hejwowski, M. Szala, Urządzenie do badania odporności materiałów na zużycie kawitacyjne [ prawo ochronne nr 66576], 2013.

[23] J. Chmiel, Metody badań zjawisk zużycia korozyjno-kawitacyjnego. Stanowiska badawcze, Zeszyty Naukowe / Akademia Morska W Szczecinie. nr 5 (77) (2005) 179-192. 